Geology, Geophysics \& Environment • 2012 • Vol. 38 • No. 1 • 9-22

http://dx.doi.org/10.7494/geol.2012.38.1.9

\title{
GROUND UPLIFT \\ AFTER THE CLOSURE OF WATER LEAKS IN THE MINA DRIFT OF THE WIELICZKA SALT MINE
}

\author{
Wypiętrzenia terenu po zamknięciu wycieku w poprzeczni Mina \\ w Kopalni Soli Wieliczka
}

\author{
Agnieszka Maj ${ }^{1}$, Grzegorz Kortas ${ }^{1} \&$ Paweł Ulmaniec $^{2}$

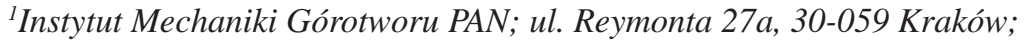 \\ e-mail:maj@img-pan.krakow.pl \\ ${ }^{2}$ Kopalnia Soli Wieliczka SA; Park Kingi 1, 32-020 Wieliczka; \\ e-mail:pawel.ulmaniec@kopalnia.pl
}

\begin{abstract}
After putting the water leaks in the Wieliczka Salt Mine under control, upon construction of dams in 2007, the ground subsidence stopped. Presently, however, ground uplifts are observed on land surface. This paper presents geological, mining, and hydro-geological conditions occurring in the leak areas. Using the examples of previous subsidence, the authors have demonstrated the shaping of ground uplifts observed in levelling surveying by precise measurement methods. With a correction relating to the subsidence caused by working convergence that also occur in ground displacements, it was found that the maximum ground uplifts reached $63 \mathrm{~mm}$, with the continuing trends in the years to come. It was established that the causes of uplifting included increase of pressure in suffosion caverns and the displacement effect, with irrigation of dried and drained formations during the flow of water into the salt mine.
\end{abstract}

Key words: Wieliczka Salt Mine, subsidence trough, ground uplift

Treść: Po opanowanym wdarciu wód do Kopalni Soli Wieliczka przez zamknięcie wycieku w 2007 r. ustały obniżenia powierzchni i obecnie wykształcają się wypiętrzenia. W pracy przedstawiono warunki geologiczno-górnicze i hydrogeologiczne w strefie wycieku i na tle poprzednich obniżeń pokazano kształtowanie się wypiętrzeń terenu, obserwowane w pomiarach geodezyjnych niwelacją precyzyjną. Biorąc pod uwagę poprawkę na uczestniczące w przemieszczeniach terenu osiadania spowodowane wpływami kopalni, stwierdzono, że maksymalne wypiętrzenia osiągnęły $63 \mathrm{~mm}$, a teren w następnych latach może się nadal wypiętrzać. Wskazano, że przyczyną wypiętrzeń jest zwiększenie ciśnienia w kawernach sufozyjnych oraz efekt wypornościowy i nawadnianie osuszonych i zdrenowanych utworów w trakcie spływu wód do kopalni.

Słowa kluczowe: Kopalnia Soli Wieliczka, niecka osiadań, wypiętrzenia terenu 


\section{INTRODUCTION}

Water penetration into the Mina drift at Level IV of the Wieliczka Salt Mine in 1992 caused the occurrence of considerable deformations on the northern Salt Mine foreground. Leak containment and rock mass sealing allowed to put the water hazard under control and leak plugging in 2007. The circumstances and the course of water penetration, with its characteristics, evaluation, and threat analysis, were the objects of a number of studies and publications (e.g. Garlicki \& Wilk 1993, Studium... 1995, Bromowicz \& Brudnik 1997, Gonet et al. 1997). in this paper, we present the geological and mining conditions of the water leak area, discussed in detail in many papers (e.g. Garlicki \& Szybist 1995, Nałęcki 1995, Kortas 2004, d'Obyrn \& Przybyło 2010). Based on the results of the measurements of subsidence at the stage of leak activity, we have discussed the observed displacements that were typical for the process of natural hydro-geological condition recovery.

\section{GEOLOGICAL AND MINING CONDITIONS}

The geological structure of the border zone of the Wieliczka rock salt deposits is quite complex. The zone width is changing from $200 \mathrm{~m}$ to $500 \mathrm{~m}$. A gypsum cap is adjacent to the deposit, with distant Skawina formations, mixed with Carpathian flysch and Chodenice sandstone formations. Such formations are often torn apart and they overlap in the form of crests or scales. Sandstone blocks have the dimension of ca. $20 \mathrm{~m}$, and their accumulation is chaotic. They are shifted apart, locally separated by silt formations, and they create crevices and caverns. Finegrain, compacted or loose, and even disintegrating sandstones show the traces of karst activities and water flow. Locally, we can find within sands some fragments of the crushed gypsum cap. That zone is a path of water links of several water subsystems (Garlicki \& Wilk 1993).

The Mina drift cuts the deposit boundary at the horizon of $76 \mathrm{~m}$ a.s.l. Its northern edge overcomes the gypsum cap and opens a water link with the water contained in the Chodenice sandstone layers. The deposit structure in that area and the location of the Mina are characterized by the geological cross-section presented in figure 1.

The rock mass and land surface deformations have been shaped by primary and secondary geological conditions occurring in the Chodenice layers since the time of water penetration. Those formations isolate the deposit from the contacts with Quaternary and surface waters. Fine-grain, silted and dusty sandstones occurring there, with diverse filtration coefficients from $10^{-10} \mathrm{~m} / \mathrm{s}$ to $10^{-6} \mathrm{~m} / \mathrm{s}$, create aquiferous layers, allowing for water flows within the space between the boulders of crushed sandstones (Garlicki \& Wilk 1993). As a result zof tectonic disturbances and karst processes around the Mina drift, local systems of water circulation were created within two or three sandstone stratiforms.

The area around the Mina drift is the northern part of the central Salt Mine area. Under the Mina, there are 19th and 20th century dry extraction chambers and about a dozen of 20th century leached caverns. On the top levels, there are some chambers and gallery workings. Such workings are subjected to volumetric convergence at small rates of up to $-7.3 \%$ o/year, and locally even $-11.1 \%$ o/year. The chambers situated on Levels IV to VIII were backfilled, but convergence will stop only after the backfill obtains adequate support strength. 


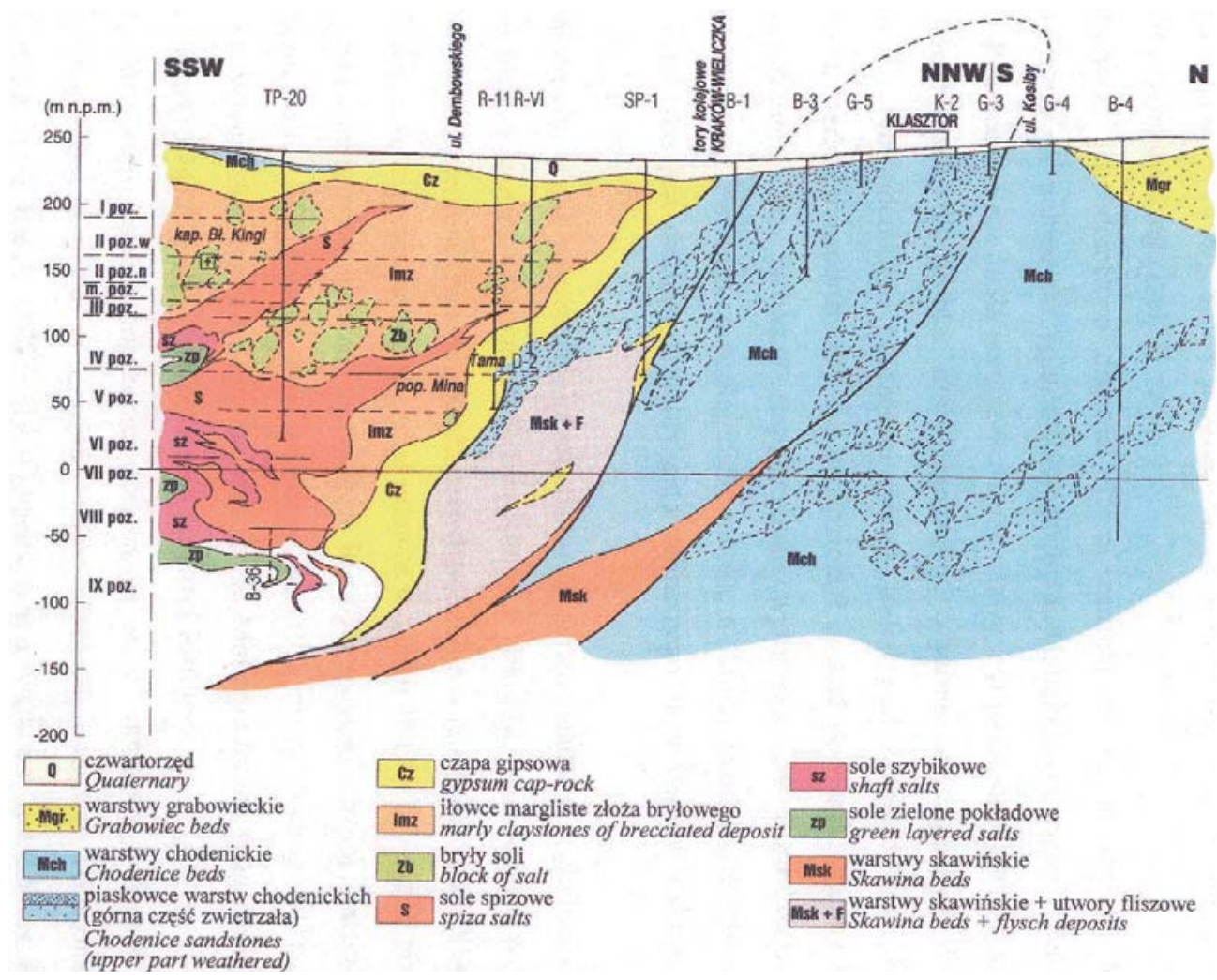

Fig. 1. Geological cross-section of the Mina drift (Ulmaniec 2004, after: Brudnik \& Szybist 1995)

Fig. 1. Przekrój geologiczny przez rejon poprzeczni Mina (Ulmaniec 2004, za: Brudnik \& Szybist 1995)

The breach of the deposit boundary in the Mina drift in 1912 caused the appearance of a leak, and $226,000 \mathrm{~m}^{3}$ of water penetrated by 1992 . With the average leaching density of $40 \mathrm{~g} / \mathrm{dm}^{3} \mathrm{NaCl}$, water entered the surface area of ca. 4,200 $\mathrm{m}^{3}$. Water penetration that occurred in 1992 initiated a number of rapid flows which changed into an almost uniform leak with decreasing yield $\left(120 \mathrm{dm}^{3} / \mathrm{min}\right.$ before plugging).

A long-term drainage of aquiferous formations caused the outflow of $45,000 \mathrm{~m}^{3}$ of insoluble parts and $\mathrm{NaCl}$ together with water. The washed rock material plugged suffosion canals, while increased water pressure made them wider. Periodic high hydraulic gradients were the cause of the suffosion processes. Periodic subsidence, with ground uplift when the leak decreased within the suffosion trough, became secondary symptoms of that process.

Plugging of the leak in 2007 started the process of reinstatement of natural hydrogeological conditions: water table increase with void filling, watering of drained formations, and rebuilding of natural pressures. The influence of those processes on the ground movements have been still observed. 


\section{GROUND DISPLACEMENTS AFTER LEAK PLUGGING IN THE MINA DRIFT}

The surveying measurements have been conducted on the northern foreground of the salt deposit since the 1920's. A dense network of observations of the uncontrolled water flow effects was established after the intense leak of 1992. in the subsequent months, the maximum ground subsidence (Benchmark S-5 and later S-300) reached $-14 \mathrm{~cm} /$ day. Recent rapid ground displacements occurred by the end of April of 1993. Later, the ground subsided at different but slowing rates from $-25 \mathrm{~mm} /$ year to $-2 \mathrm{~mm} /$ year (Figs 2, 3), until the leak was plugged. Since 2007, the ground was regularly lifting up, according to the precise surveying method measurements conducted by P. Ulmaniec (Fig. 3).

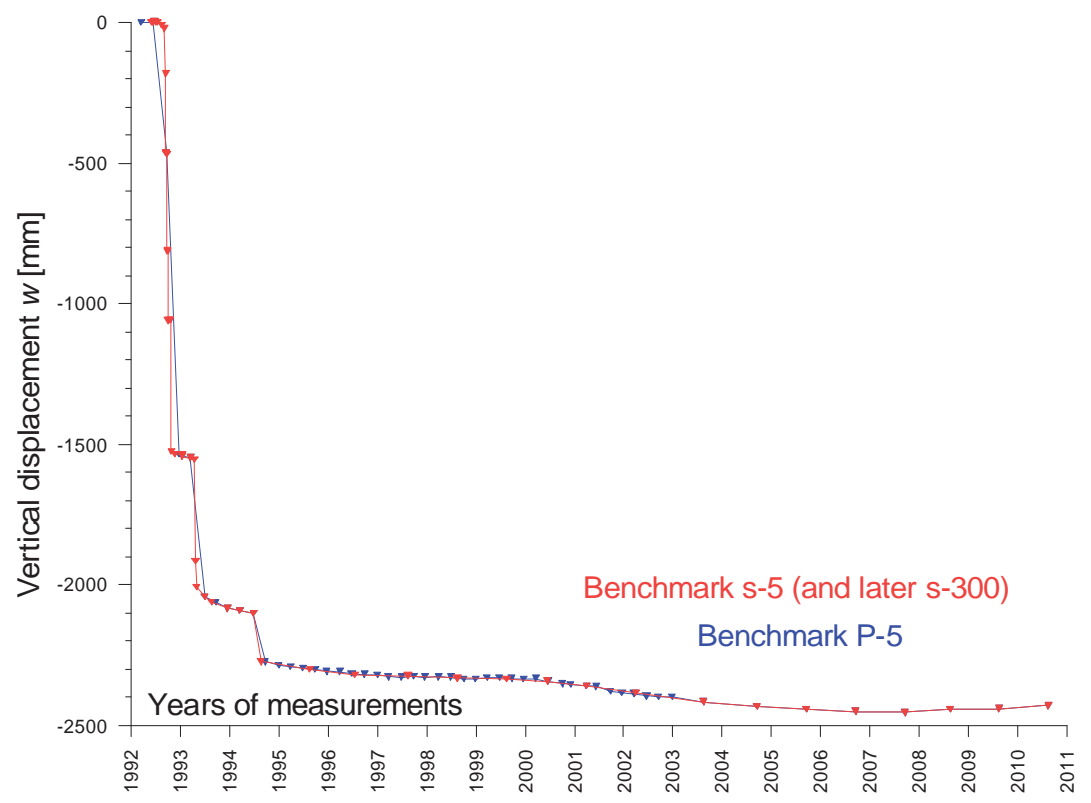

Fig. 2. Benchmark S-5 vertical displacement (Ulmaniec 2004)

Fig. 2. Przemieszczenie pionowe reperu S-5 (Ulmaniec 2004)

In the first year after leak plugging, the maximum displacement of $+21 \mathrm{~mm}$ was found at Benchmark S-206. The uplift area of more than $10 \mathrm{~mm}$ on the surface of ca. 6 hectares covered the deepest central and eastern parts of the suffosion trough. Maximum 2009 uplifts were observed at Benchmarks S-207 and S-301: $+33 \mathrm{~mm}$. The $+10 \mathrm{~mm}$ isoline of 2007-2009 covered nearly the whole area of subsidence of more than $-100 \mathrm{~mm}$ identified in the observation period of 1992-2007 (Fig. 4). 


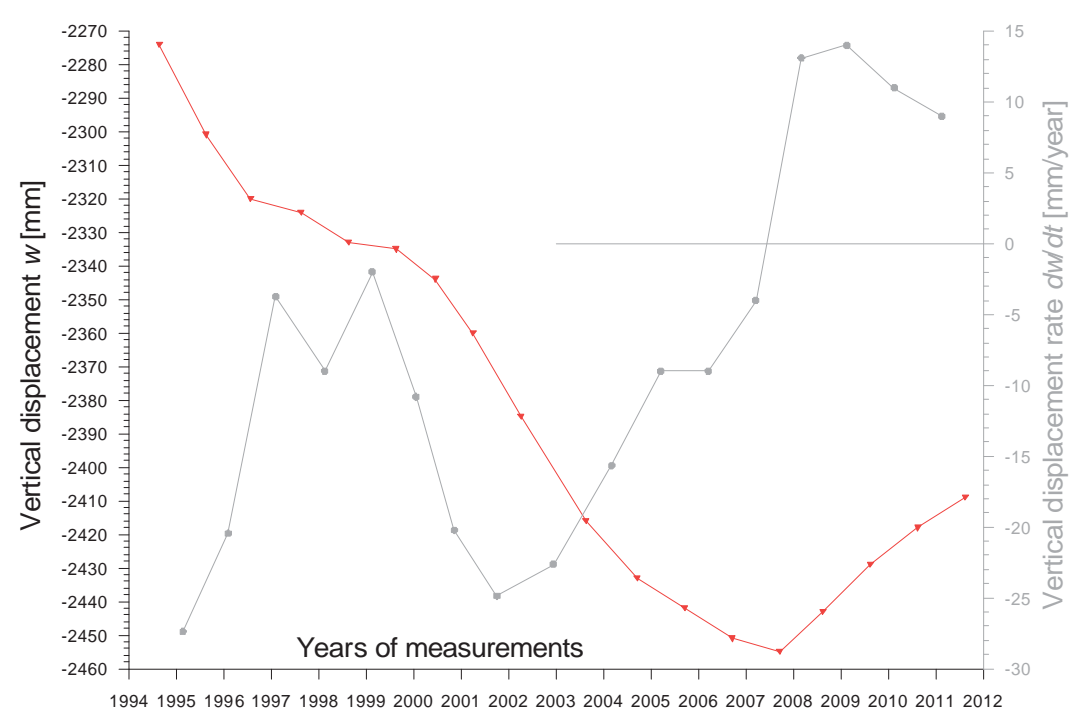

Fig. 3. Benchmark S-5 vertical displacement and displacement rate since 1995

Fig. 3. Przemieszczenie pionowe reperu S-5 i prędkość przemieszczenia od 1995 r.

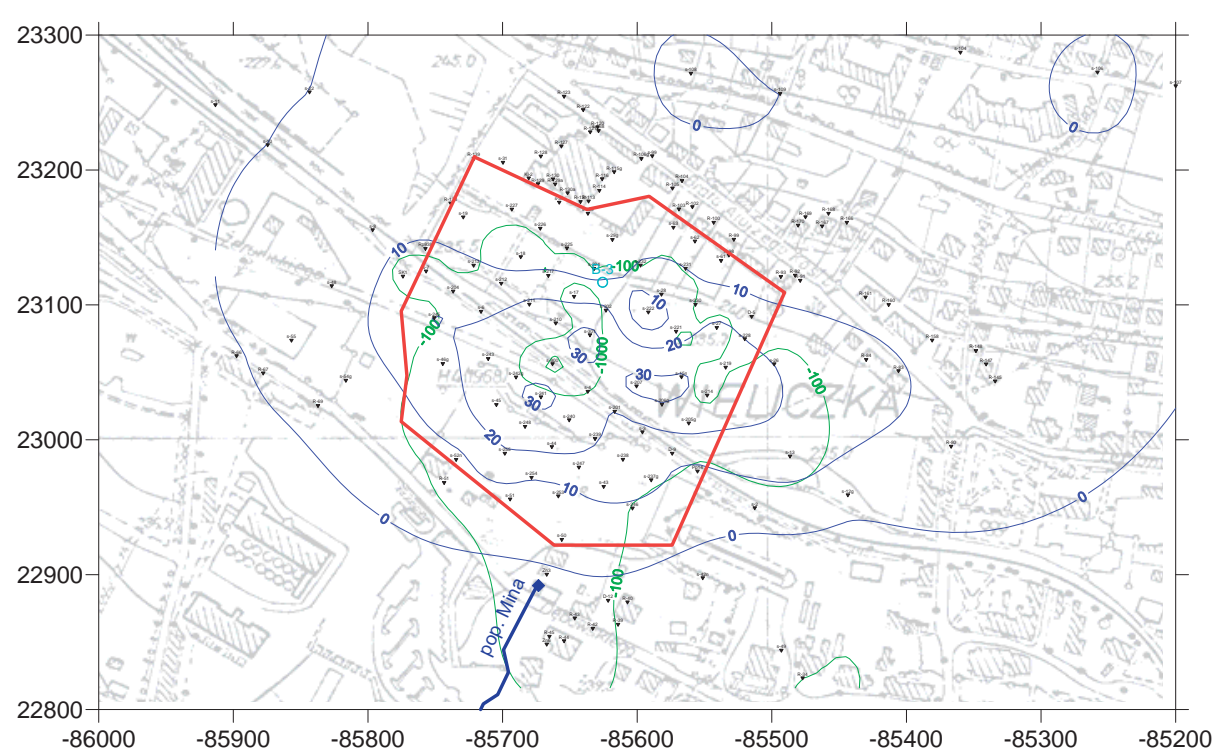

Fig. 4. Distribution of uplifts after leak plugging in the Mina drift in 2007-2009, in mm

Fig. 4. Rozkład wypiętrzeń po zamknięciu wycieku w poprzeczni Mina w okresie 2007-2009, w milimetrach 
By 2010, the maximum uplifts occurred behind the railway line, $200 \mathrm{~m}$ north from the leak dam, and they reached the value of $+49 \mathrm{~mm}$.

In total, the maximum uplifts after leak plugging by autumn of 2011 amounted to $+63 \mathrm{~mm}$, with slight expansion of the +10 isoline (Fig. 5), and uplift volume of ca. $2,300 \mathrm{~m}^{3}$.

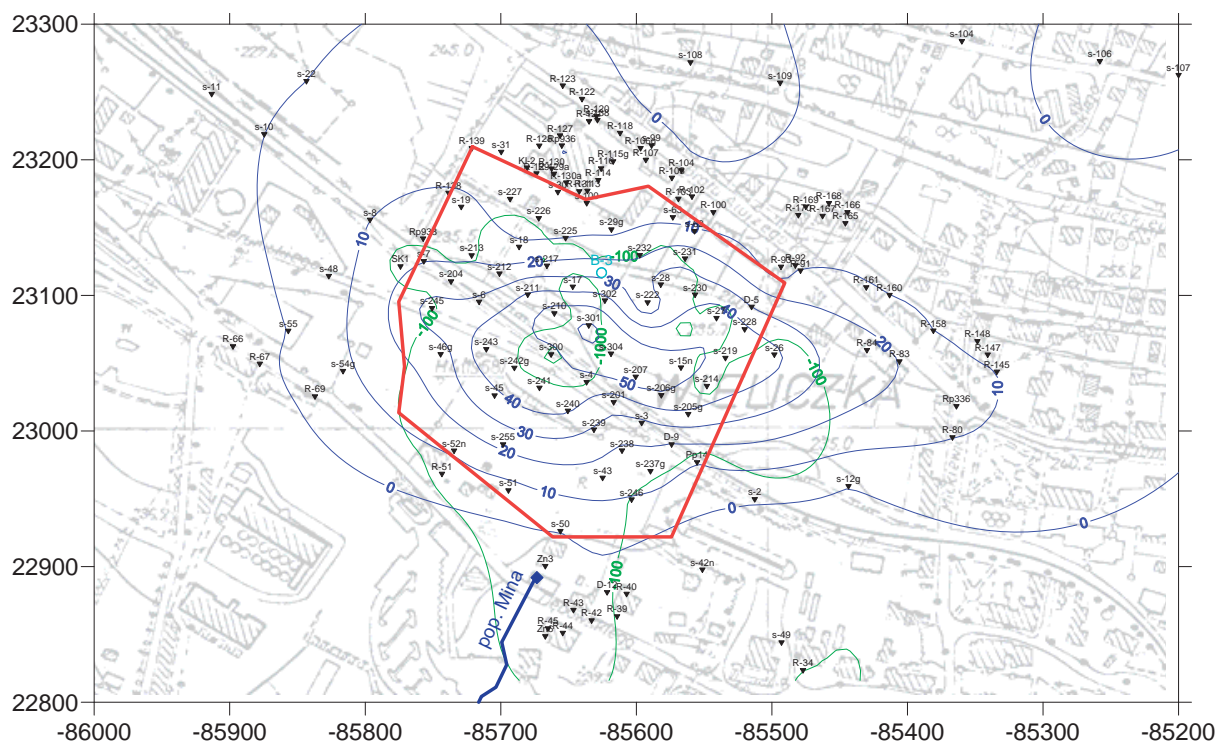

Fig. 5. Distribution of uplifts after leak plugging in the Mina drift in 2007-2011, in mm

Fig. 5. Rozkład wypiętrzeń po zamknięciu wycieku w poprzeczni Mina w okresie 2007-2011, w milimetrach

\section{ANALYSIS OF GEODETIC GROUND MOVEMENT OBSERVATIONS}

The comparison of subsidence occurring before leak plugging and afterwards can be demonstrated on the example of several benchmarks placed in the trough centres in various periods. We observed change from subsidence to uplifts on all benchmarks, with more and more regular uplift rates (Fig. 6).

The shaping of the uplift trough is illustrated with cross-sections. in the 1992-2007 trough cross-sections were dominated by the effects of rapid and considerable subsidence caused by rock mass dehydration and suffosion of 1992-1993 (Fig. 7).

In the first year of uplift observation, the trough was shaping on both sides of the railway line, above the subsidence centre of the previous period and at the sandstone outcrop. in the subsequent years, the southern centre disappeared, and the maximum uplifts were found above the sandstones, with a typical trough elongation on the sandstone stretch. 

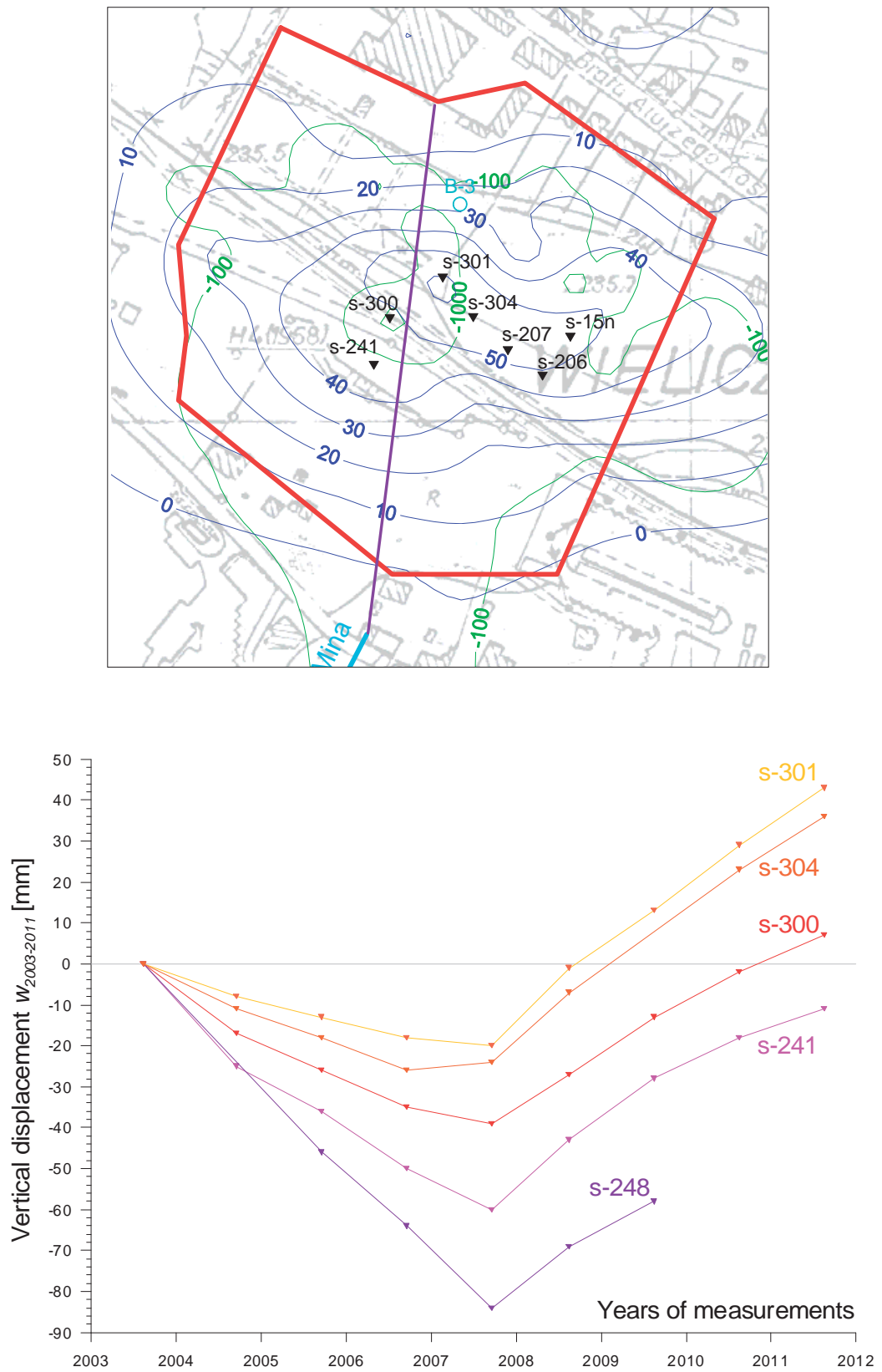

Fig. 6. Locations of benchmarks and cross-section lines, with vertical displacement of annual trough centres in 2004-2011

Fig. 6. Lokalizacja reperów i linii przekroju oraz przemieszczenia pionowe centrów rocznych niecek w latach 2004-2011 


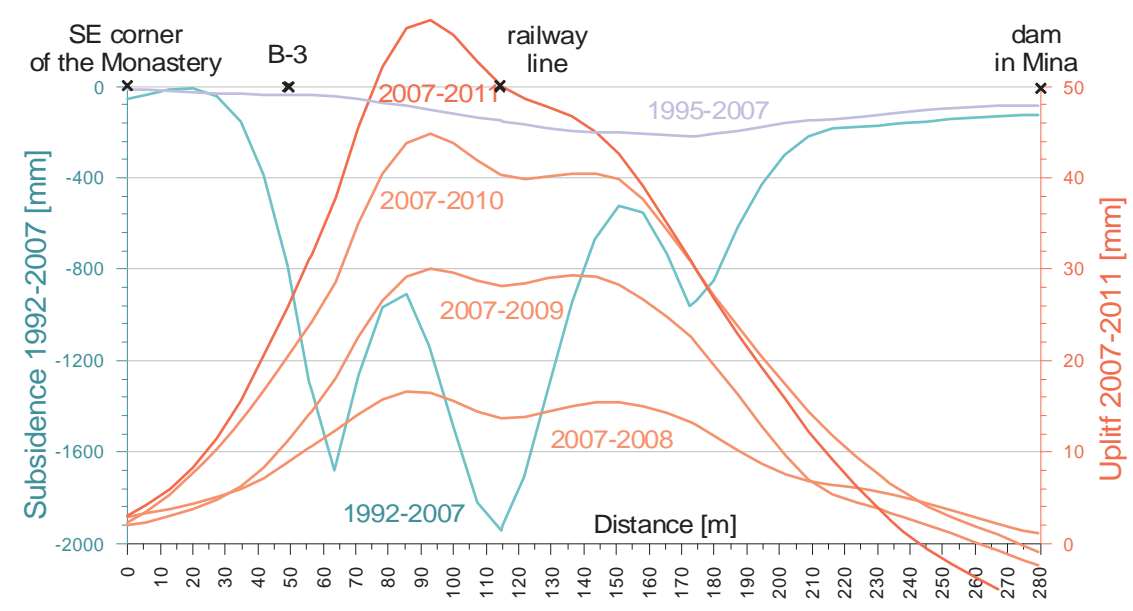

Fig. 7. N-S subsidence trough profiles and uplifts shaping

Fig. 7. Profile N-S niecek obniżeń i kształtowanie się profilu niecki wypiętrzeń

The observed vertical displacements are the total results of the uplift caused by rebuilding water table and land subsidence caused by the mine workings convergence. The constant rate of volumetric convergence is associated with the constant rates of land subsidence, also on the related surface. For that reason, the actual sizes of the uplifts caused by filling of the depression funnel by water are getting larger. We can infer from our observation of subsidence before water penetration into the Mina drift that the areas of the trough centre subsided with the range of ca. $-4 \mathrm{~mm} /$ year. Assuming that similar subsidence results from the current influence of the converging workings on the land surface, we can correct elevations of Benchmark S-241 and S-304 to $+16 \mathrm{~mm} / 4$ years. The correction results are visible on the benchmark uplift graphs (Fig. 8) and the profiles of figure 9.

Implementation of that correction leads to a change of the uplift distribution and increase of the uplifted mass volumes to $V_{w}=2,600 \mathrm{~m}^{3}$. The range of the uplift trough is enlarging towards the Mina drift, and the southern trough slope is getting milder (Fig. 9).

The piezometric water level measurements taken in Borehole B-3 indicate that two separate rates of water level increase appeared during the depression funnel filling. Initially, after Pipe D-1 was removed, the rate was $k_{1}=8 \mathrm{~m} /$ year. Later, after the damper was closed on Pipes D-2 and D-3, the rate decreased to $k_{2}=3 \mathrm{~m} /$ year (Fig. 10). The range change was also reflected in benchmark uplifting.

The volume of the original voids and those created during rock uplifting was estimated at $V_{p}=11,500 \mathrm{~m}^{3}$ (Kortas \& Maj 2011). Consequently, the proportion of the trough uplift volume to the void volume is $V_{w} / V_{p}=0.23$. The uplifts caused by elastic mechanical reaction resulted from increasing pressure on void walls, proportionally to the height of the water level, as well as the displacement effect. Formation swelling, especially clay swelling caused by humidity was another reason of that process. in the first year, the subsidence and uplift 
centres were matching, and the effects of mechanical reaction were dominating uplift components. Positive volumetric convergence and upward directed vertical displacements developed in suffosion caverns. Later, the trough uplift centre moved north. That could have been caused by the filling of shallow voids situated in sandstone outcrops, although the duration of the process indicates that the results of previously drained and dried formation watering could be dominating.
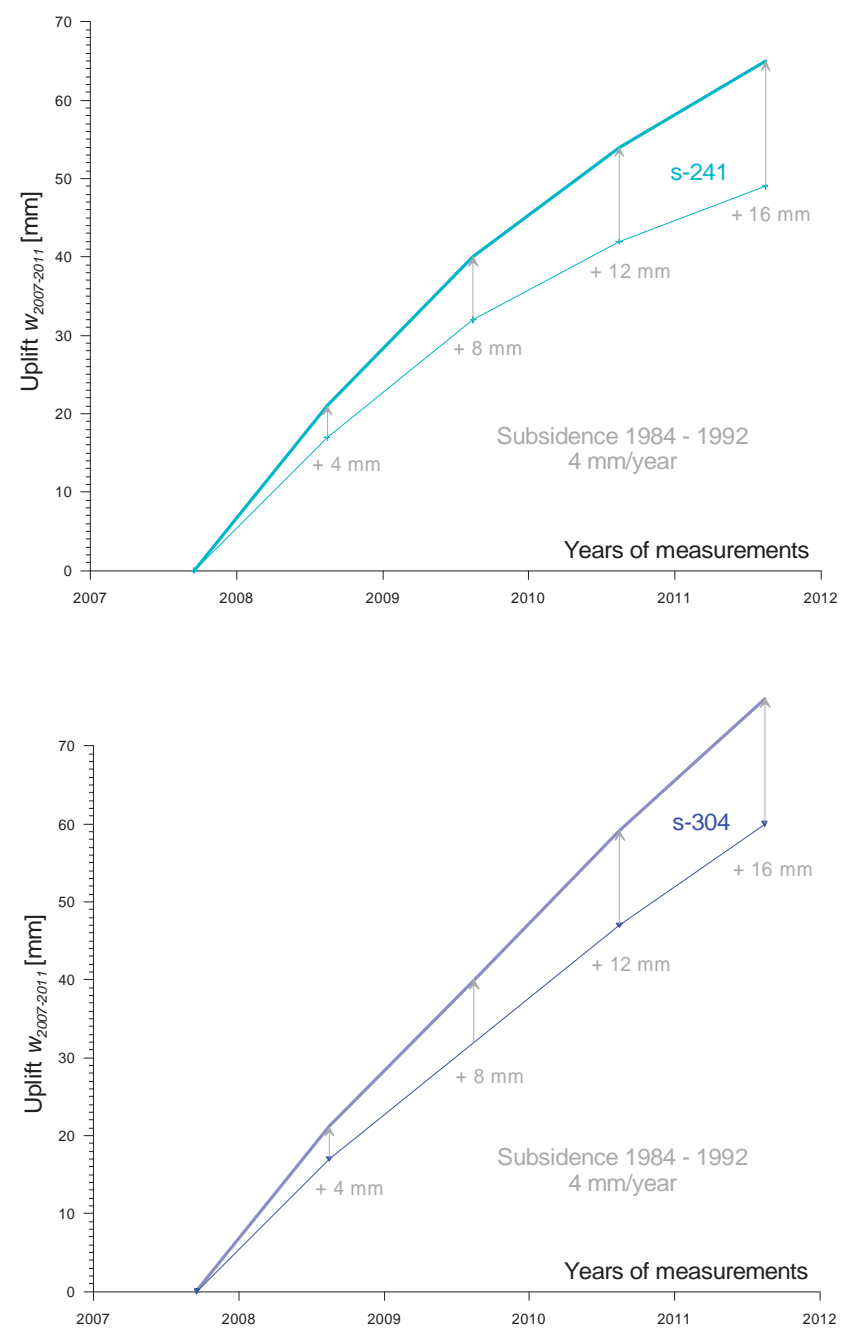

Fig. 8. Benchmark S-241 and S-304 uplifts after accounting for the workings uplift influence on the surface

Fig. 8. Wypiętrzenie reperów S-241 i S-304 po uwzględnieniu wpływów na powierzchnię terenu zaciskania wyrobisk 
A. Maj, G. Kortas \& P. Ulmaniec

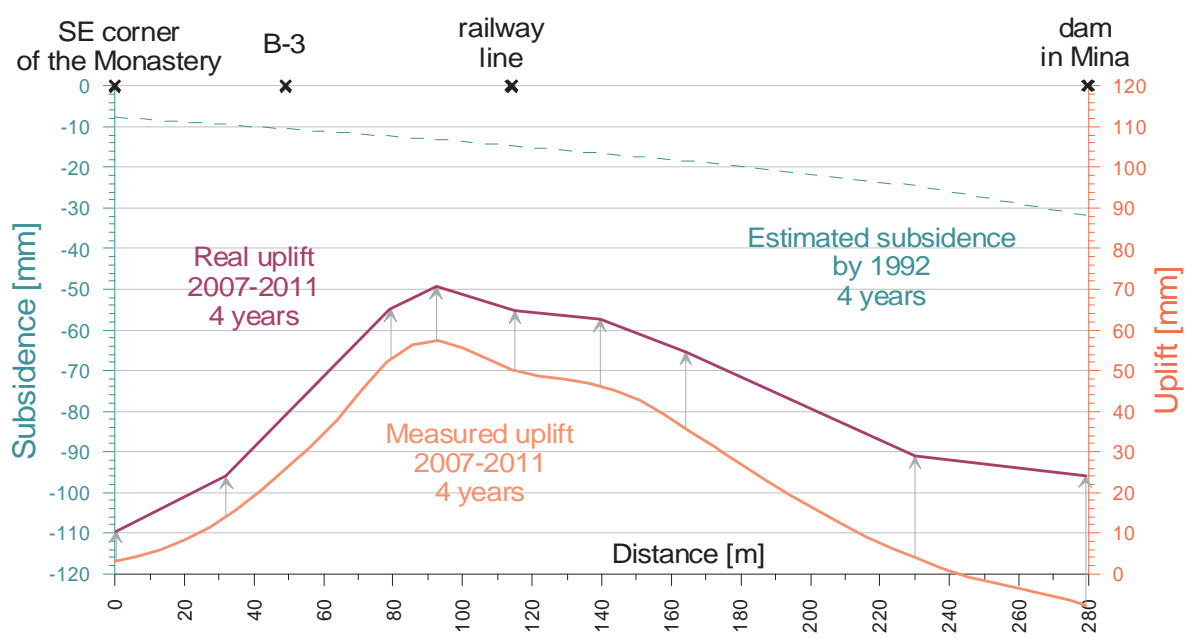

Fig. 9. Imposition of the land subsidence and uplifting processes

Fig. 9. Nakładanie się procesów osiadania wypiętrzania terenu

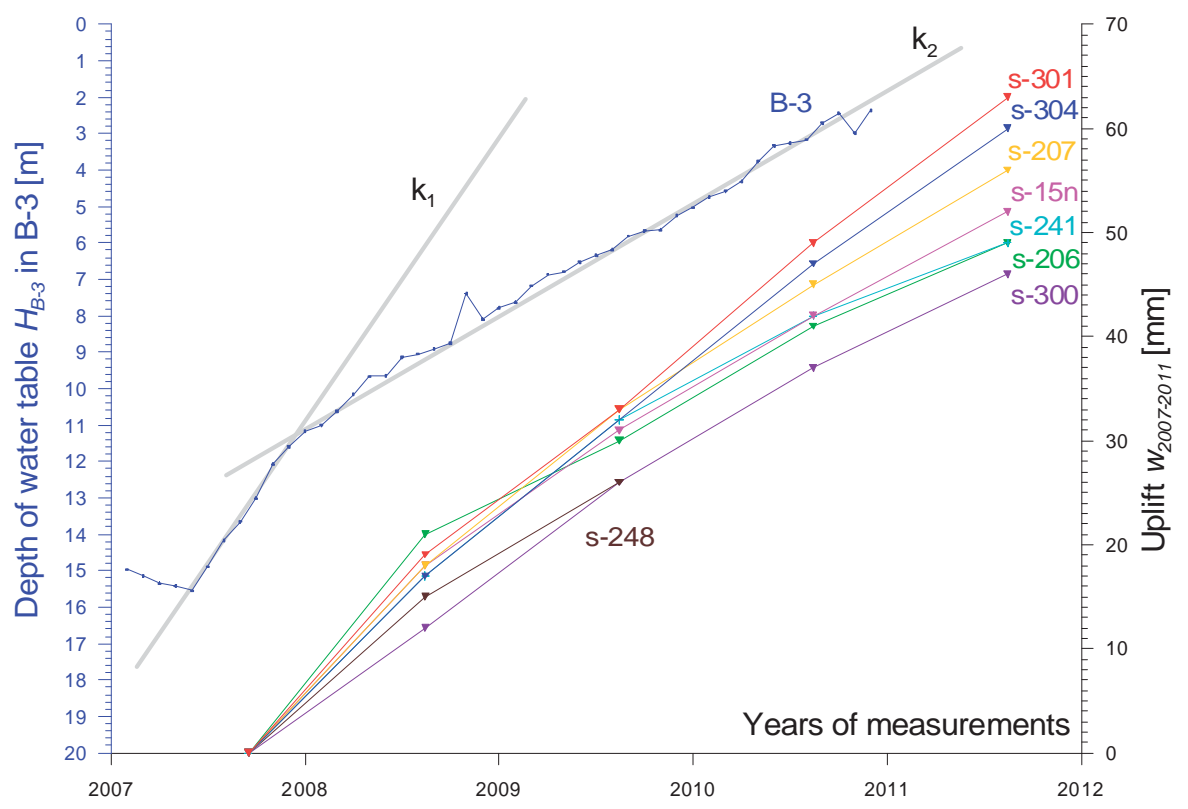

Fig. 10. Results of the observation of piezometric water level depth in Borehole B-3 and of benchmark uplifts after leak plugging in the Mina drift

Fig. 10. Wyniki obserwacji głębokości zwierciadła wody w otworze B-3 i wypiętrzenia reperów po zamknięciu wycieku w poprzeczni Mina 
The secondary effect of the reinstatement of the previous hydro-geological conditions may include temporary increase of the rock mass activity. It is visible on the upper salt mine levels. Previously subsiding drifts were uplifted above the Mina drift after 2007.

Survey of surface ground displacements indicated that the process of reinstatement has not been completed in comparison to the status existing before water penetration. The uplifts resulting from pressure increase in the water filled caverns will stop only after complete disappearance of the depression funnel and clay swell ending. Those processes will be indicated by uplift and subsidence stopping, similarly to the stopping of subsidence before 1992 . We should emphasize, however, that the influx of water to the catchment area drained until 2007 was not large, while the leak amounted to ca. 120-170 1/min in the Mina drift. A limited influx was the basic circumstance which allowed miners to put leaks under control after 1992. Consequently, with the same influx rate, the period of filling of the drained catchment area will take many years, and long-term ground movements can be expected.

\section{SUMMARY AND CONCLUSIONS}

1. Water penetration into the Mina drift in 1992 caused serious threat to the salt mine and the lands situated on the mine's northern foreground. After leak plugging in 2007, water influx was stopped, and small regular uplifts were noticed on the surface on the areas of previous subsidence. in reference to previous subsidence, we presented in our paper the distribution of land uplifting and how they are related to hydro-geological and geo-mechanical conditions.

2. Ground movements have been controlled since leak plugging by annual benchmark height measurements, using the precise levelling method whose mean error does not exceed $\pm 1 \mathrm{~mm}$.

3. The uplifting trough is situated on the area of previous subsidence, with its centre located north of the railway line. Maximum 2007-2011uplifts reached $+63 \mathrm{~mm}$, and the trend indicates that the process will continue in the next years to come. The trough has the shape of an elongated ellipse whose longer side is situated over the sandstone outcrop.

4. The displacements observed on the land surface show the accumulation of :

- pressure changes taking place in the suffosion caverns that developed during uncontrolled water flow,

- the displacements effect resulting from the depression funnel filling and watering of previously dried formations, especially clays, in the Chodenice sandstone areas,

- regular influence of mine workings convergence which were accounted for in the calculations of the actual ground uplift.

5. Uplift slowing and appearance of subsidence, with the distribution similar to that observed before water penetration into the Mina drift, will indicate the conclusion of the process of reinstatement of previous hydro-geological conditions after leak plugging.

The authors would like to thank the managers of the Wieliczka Salt Mine for their kind assistance in giving access to documentary and archival materials. 


\section{REFERENCES}

Bromowicz A. \& Brudnik K., 1987. Raport z wykonania programu prac dla likwidacji zagrożenia wodnego od wycieku WIV-27 w poprzeczni Mina. Archiwum Działu Geologicznego Kopalni Soli „Wieliczka” SA (typescript).

Garlicki A. \& Wilk Z., 1993. Geologiczne i hydrogeologiczne tło awarii na poziomie IV kopalni soli Wieliczka. Przeglad Geologiczny, 3, 1993, 183-192.

Garlicki A. \& Szybist A., 1995. Ogólne założenia dla zabezpieczenia Kopalni Soli Wieliczka oraz nowy obraz geologiczny złoża wielickiego. Materiały z III Spotkania Polskiego Stowarzyszenia Górnictwa Solnego „Likwidacja zagrożenia wodnego dla zabezpieczenia Kopalni Soli Wieliczka”.

Gonet A., Brudnik K. \& Stryczek S., 1997. Zabezpieczenie Kopalni Soli „Wieliczka przed zagrożeniem wodnym w otoczeniu poprzeczni „Mina”. Bezpieczeństwo Pracy i Ochrona Środowiska w Górnictwie, Miesięcznik WUG, 12 (40), 20-27.

Kortas G. (red.), 2004. Ruch górotworu i powierzchni w otoczeniu zabytkowych kopalń soli. Wydawnictwo Instytutu Gospodarki Surowcami Mineralnymi i Energią PAN, Kraków.

Kortas G. \& Maj A., 2011. Analiza wraz z interpretacją wyników pomiarów deformacji powierzchni w zwiazku z wyciekiem Mina w Kopalni Soli , Wieliczka” w aspekcie ochrony powierzchni. Archiwum Działu Mierniczego Kopalni Soli „Wieliczka” SA (typescript).

Nałęcki T., 1995. Warunki hydrogeologiczne. W: Mazurkiewicz M. (red.), Kompleksowa koncepcja zabezpieczenia zabytkowej kopalni soli Wieliczka przed zagrożeniem wodnym. Studium możliwości likwidacji zagrożenia wodnego dla zabytkowej kopalni soli Wieliczka za pomoca bariery drenażowej lub ekranu izolującego. Projekt Badawczy Zamawiany nr PBZ 066-01, Archiwum Działu Geologicznego Kopalni Soli „Wieliczka" (typescript).

d’Obyrn K. \& Przybyło J., 2010. Rozpoznanie geologiczne złoża soli kamiennej „Wieliczka” do 1945 roku. Przegląd Górniczy, 3-4, 110-121.

Studium możliwości likwidacji zagrożenia wodnego dla zabytkowej kopalni soli Wieliczka za pomoca bariery drenażowej lub ekranu izolujacego. Projekt Badawczy Zamawiany nr PBZ 066-01, Archiwum Działu Geologicznego Kopalni Soli „Wieliczka” (typescript).

Ulmaniec P., 2004. Badanie deformacji powierzchni terenu nad wyciekiem „Mina” na poziomie IV kopalni wraz z interpretacja wyników. Wieliczka.

\section{Streszczenie}

Wdarcie wód do poprzeczni Mina na IV poziomie Kopalni Soli w Wieliczce w 1992 r. spowodowało powstanie znacznych deformacji na północnym przedpolu kopalni. Ujęcie wycieku i uszczelnienie górotworu pozwoliło na opanowania zagrożenia kopalni, a w 2007 r. na zamknięcie wycieku.

Procesy deformacji górotworu i powierzchni terenu od czasu wystąpienia wdarcia wód do chwili obecnej kształtowane są przez pierwotne i wtórne warunki hydrogeologiczne 
w utworach warstw chodenickich (Fig. 1). Zamknięcie wycieku w 2007 r. rozpoczęło proces przywracania naturalnych warunków hydrogeologicznych: podnoszenia poziomu wód z wypełnianiem pustek, nawadnianiem zdrenowanych utworów i odbudowaniem naturalnych ciśnień. Wpływ tego procesu na ruchy terenu nadal jest obserwowany.

Pomiary niwelacyjne na północnym przedpolu złoża prowadzone są od lat 20. ubiegłego wieku. Zagęszczoną sieć dla obserwacji skutków niekontrolowanych przepływów wód założono po pojawieniu się intensywnego wypływu w 1992 r. Gwałtowne ruchy terenu osiągały -14 cm/dobę (reper S-5 i potem S-300). Po 1993 r. teren obniżał się z nierównomierną, ale malejącą prędkością od $-25 \mathrm{~mm} /$ rok do $-2 \mathrm{~mm} /$ rok (Fig. 2, 3), aż do zamknięcia wycieku. Od 2007 r. teren systematycznie się wypiętrza (Fig. 3).

Maksymalne wypiętrzenia w 2009 r. zaobserwowano na reperach S-207 i S-301: +33 mm. Izolinia +10 mm w okresie 2007-2009 r. objęła prawie cały obszar zasięgu osiadań ponad $-100 \mathrm{~mm}$ z okresu obserwacji w latach 1992-2007 (Fig. 4). Do jesieni 2011 roku wypiętrzenia wyniosły $+63 \mathrm{~mm}$, jednocześnie zasięg izolinii $+10 \mathrm{~mm}$ nieznacznie się powiększył (Fig. 5), a objętość wypiętrzeń osiągnęła wartość ok. 2.3 tys. m³. Wypiętrzenia obserwowane są na wszystkich reperach w rejonie niecki sufozyjnej (Fig. 6).

W profilu niecki 1992-2007 dominują skutki gwałtownych i znacznych obniżeń spowodowanych odwadnianiem górotworu i sufozją w latach 1992-1993 (Fig. 7).

W pierwszym roku obserwacji wypiętrzeń niecka wykształcała się po obu stronach toru kolejowego, nad centrum obniżeń w poprzednim okresie oraz nad wychodną piaskowców. W kolejnych latach centrum południowe zanika, a maksima wypiętrzeń sytuują się nad piaskowcami z charakterystycznym wydłużeniem formy niecki w kierunku rozciągłości piaskowców.

Obserwowane przemieszczenia pionowe są sumą wypiętrzania wywołanego odbudową zwierciadła wodnego i obniżania terenu wynikających z zaciskaniem wyrobisk kopalnianych. Po uwzględnieniu poprawki na stałe osiadanie terenu wywołane równomierną konwergencją wyrobisk rzeczywiste wartości wypiętrzeń spowodowanych wypełnianiem się leja depresji wód są większe (Fig. 8). Wprowadzenie tej poprawki prowadzi do zmiany rozkładu wypiętrzeń (Fig. 9) i wzrostu objętości podnoszonych mas do $V_{w}=2.6$ tys. $\mathrm{m}^{3}$. Objętość pustek pierwotnych i powstałych w trakcie wynoszenia materiału skalnego oszacowano na $V_{p}=11.5$ tys. $\mathrm{m}^{3}$, zatem stosunek objętości niecki wypiętrzeń do objętości pustek wynosi $V_{w} / V_{p}=0.23$.

Z pomiarów poziomu zwierciadła wody w otworze B-3 wynika, że w trakcie wypełniania się leja depresji występowały dwie odrębne prędkości podnoszenia poziomu wody. Początkowo, po likwidacji rury D-1, prędkość ta wynosiła $k_{1}=8 \mathrm{~m} /$ rok. Później, po zamknięciu zasuwy na rurach D-2 i D-3, prędkość spadła do $k_{2}=3 \mathrm{~m} /$ rok (Fig. 10). Zmiana tych prędkości odzwierciedla się także w wypiętrzeniach reperów.

Wypiętrzenia spowodowane są sprężystą reakcją mechaniczną wywołaną wzrostem ciśnienia na ściany pustki, rosnącego proporcjonalnie do wysokości zwierciadła wody, a także efektem wypornościowym. Inną przyczyną jest pęcznienie utworów, szczególnie iłów, spowodowane ich namakaniem. W pierwszym roku centra obniżeń i wypiętrzeń pokrywają się, 
więc dominującą składową wypiętrzeń były skutki reakcji mechanicznej. Potem centrum niecki wypiętrzeń przesuwa się na północ. Powodem tego może być wypełnianie płytko rozmieszczonych pustek na wychodniach piaskowców, ale długotrwałość procesu wskazuje, że dominujące mogą być skutki namakania poprzednio zdrenowanych i osuszonych utworów.

Symptomem zakończenia procesu przywracania warunków hydrogeologicznych po zamknięciu wycieku będzie spowolnienie wypiętrzeń i pojawienie się osiadań o rozkładzie podobnym do obserwowanego przed wdarciem wód do poprzeczni Mina. 